Atsumi Ueda, MEd

Hiroshima University, Graduate School of Education,

Takuya Baba, PhD

Hiroshima University, Graduate School of Education, Hiroshima, Japan

Taketo Matsuura, MEd

Hiroshima University, Graduate School of Education, Hiroshima, Japan

\title{
Values in Japanese Mathematics \\ Education from the Perspective of Open-ended Approach
}

\begin{abstract}
Mathematics education community in Japan has continuously and extensively developed 'mathematical thinking' as an educational value. In this paper, the historical review was conducted on mathematical thinking in terms of its evaluation and educational method, textbook change, and research on treatment of diversified mathematical thinking. This approach can provide methodologically an important perspective to grasp, clarify and make relative the values in mathematics education in different times of each culture. Values here mean those attitudes which lay at the back of the intention, judgment, and selection of teaching-learning activity exhibited by primary teachers. As a result of this research, it is learnt that the theme in mathematics education research does reflect values held by the primary mathematics teachers. They, in turn, have held central ideas and value utilizing children's diversified mathematical thinking, letting them subjectively and extensively construct mathematical ideas in the lesson. The major characteristics of Japanese Mathematics education is the open-ended approach, which has been developed as an evaluation and educational method of mathematical thinking. This is available as translated version of "The Open-Ended Approach: A New Proposal for Teaching Mathematics" (The original version (Shimada) is in Japanese published in 1977).
\end{abstract}

Keywords: Value, Open-ended approach, Historical analysis, Mathematical Thinking.

\section{Introduction}

The Teaching Gap: Best Ideas from the World's Teachers for Improving Education in the Classroom

1 takuba@hiroshima-u.ac.jp
(Stigler \& Hiebert, 1999) called in earnest for attention to be paid to the lesson study and Mathematics education in Japan, where the lesson study has been developed. In the same vein, a few other international efforts sought to introduce Japanese Math- 
ematics education to the international community, and one of the typical ones is EARCOME 5 (East Asian Regional Conference on Mathematics Education). Such efforts are rooted in the regional characteristic of Japan however, and they tend to be bound by Japanese perspective. The two mentioned initiatives however, start to raise fundamental questions over what introducing the Mathematics education in a particular country such as Japan means, what is first of all the Mathematics education in Japan like, and what has been valued in Japanese Mathematics education by many people who have been involved in it. In return, these questions create the necessity of reflecting and giving some answers.

In 2006, JASME (Japan Academic Society of Mathematics Education) held the symposium during the $22^{\text {nd }}$ annual conference with the theme of Cultural Aspects of Mathematics Education in Japan with a focus on Mathematical Thinking. It aimed at grasping and describing 'mathematical thinking' as an educational principle, which mathematics education community in Japan has continuously and extensively valued and developed, and exploring the future direction of it through the reflection on its characteristics. The symposium confirmed that the whole clothe of mathematics education in Japan has developed coherently with mathematical thinking being as it were its warp and social and historical needs as its weft (Baba, 2006).

In this paper, the persisting values of mathematics education community in Japan are reflected from teachers' perspective as an example of openended approach. Here the values mean "those of primary teachers at the back of their intention, judgment, and selection of teaching-learning activity" (Baba et al., 2013). The open-ended approach is a good example in order to relativise and reflect characteristics of Japanese mathematics education, because it retains those characteristics developing around mathematical thinking and diverse ideas, and it can be also referred by international researchers since it is available as translated version "The
Open-ended Approach: A New Proposal for Teaching Mathematics" (Becker \& Shimada) published in 1997.

The open-ended approach is typically exemplified as the developmental work with Open-ended approach in Mathematics Education - New Proposal of Lesson Improvement (Shimada, 1977) and From Problem to Problem -Extensive Treatment of Problems for Improvement of Mathematics Lesson (Takeuchi \& Sawada, 1984). This extensive treatment of mathematical problems is seen as an extension of Open-ended approach, and thus it is included in it.

\section{Emergence of Mathematical Thinking as the Objective in the Course of Study}

The term "mathematical thinking", which is a translation of "suugakutekina-kangaekata", first appeared in 1958 in the objective of the course of study for primary education. The course of study was developed in Japan after the WWII and was intended to be the national curriculum in Japan. Its objectives at the time were as follows:

1. To enable students to understand basic concepts and principles about numbers and quantities, and geometrical figures, and let them develop more advanced mathematical thinking and how to treat it.

2. To enable students to acquire basic knowledge and fundamental skills about numbers and quantities, and geometrical figures, and let them use those effectively and efficiently according to the purpose.

3. To enable students to understand the significance of using mathematical terms and symbols, and let them use expression and think simply and clearly quantitative events and relations using the terms and symbols. 
4. To enable students to extend the abilities to set up a appropriate plan and to think logically regarding quantitative events and relations, and let them treat things more self-dependently and rationally.

5. To enable students to develop attitudes towards a proactive mathematical thinking and how to treat it in daily life. (Underlined by the authors.)

The phrase "mathematical thinking and how to treat it" in this objective is commonly referred as "mathematical thinking" to mean all components related to this mathematical thinking and treatment. From the above, it is expected to develop the acquired fundamental concepts and basic skills to the more advanced level and to grow the attitudes to apply them extensively to daily life situation. Historically speaking, the mathematical idea ${ }^{2}$ as philosophical stance in national textbook Jinjo-shogakusanjutsu used since 1935 preceded the mention of mathematical thinking (Ueda, 2006). So in this sense, there was a continuing aspiration of Japanese mathematics education community despite of temporal mutation during the WWII.

The community at the time tried to uplift the lowering standards of mathematics education when the term 'mathematical thinking' emerged, after the critical reflection over the life unit learning which placed mathematics education as skills-based subject (Nakashima, 1981). In other words, the community aimed at raising efficiency by teachers' clarifying and extending the basic ideas and principles through mathematical thinking. Through development of mathematical thinking abilities, students would have been able to find out new ideas subjectively and use appropriately and efficiently mathematical facts and relations, express and think of them in a concise and clear way, and treat them in-

2 Mathematical ideas are philosophical attitudes to love and enjoy mathematical philosophy in pursuit and acquisition of mathematical truth, and to find and consider the mathematical relation in the daily events and to take an action based on them (Shiono, 1970). dependently and rationally. Despite these intentions, the meaning of mathematical thinking at the time was not clear enough to the majority of teachers expected to teach it.

Just before the emergence of the concept of mathematical thinking, there was a preceding idea, called the central concepts. The term first appeared in the course of study for the senior high school in 1956. The characteristics of this course of study were the integration of Analysis I, Analysis II and Geometry into Mathematics I, Mathematics II and Mathematics III as mathematical subjects. At that time, central concepts exemplified mathematical thinking as central ideas to bridge all the content of each mathematical subject although they were shown separately in terms of the algebraic and geometrical contents. For example, the central ideas for Mathematics I were described as follows:

a. Expressing the concepts in symbols

b. Extending concepts and laws

c. Systematizing knowledge by deductive reasoning

d. Grasping relation of correspondence and dependence

e. Finding out invariance of equation and geometrical figures

f. (Identifying) Relations between analytical and geometrical methods.

The central ideas had an intention to integrate algebra and geometry in mathematics as one subject and to extract mathematical methods and activities common to both of them. They are not exactly the same as mathematical thinking, which has become an objective of primary mathematics education, but it certainly had an influence on its introduction. When the course of study was revised in 1968 to introduce the idea of modern mathematics movement, it further emphasized the mathematical thinking we have been talking about.

The table 1 shows the name of sessions and the number of presentations in the session during 
the annual conference by the Japan Society of Mathematics Education (JSME). When the course of study was revised in 1968, the sessions on the newly introduced topics such as sets, function and probability and statistics were created in addition to the existing ones such as number and calculation, quantity and measurement, geometrical figures. The session of mathematical thinking was created only 6 years later in 1973. In other words, discussion over mathematical thinking started after discussion over the above contents had reached a certain level.

\section{Efforts analyzing and defining the mathematical thinking}

Around the time of setting the session at the JSME in 1973, the analysis on concepts of mathematical thinking had already started. Katagiri of Tokyo Metropolitan Institute of Education ushered in the concept into his analysis Mathematical Thinking and its Teaching (Katagiri et al.) in 1971 and categorized mathematical thinking into three types. These were identified as a) the attitudinal aspects of mathematical thinking

b) the process aspects of mathematical thinking such as generalization and analogy, and

c) the contents related mathematical thinking such as unitary amount and relative amount.

In 1981 Nakashima published Mathematical Thinking at Primary and Secondary Mathematics Education, and stated that mathematical thinking consisted of abilities and attitudes to work autonomously and have an ability to apply these creatively through an activity appropriate to mathematics education. He clarified that to develop mathematical thinking, one had to pay attention to this autonomous and creative process within an activity.

In 1988, Katagiri reorganized the above categorization of mathematical thinking into mathematical thinking related to methods and contents. Through these publications, interpretation of mathematical thinking has been gradually clarified in Japanese context. As we have seen so far, Katagiri and Nakajima have been the most famous researchers that contributed to analytical research on mathematical thinking in Japan.

Table1. Sessions and Number of Presentations at Annual conference of JSME (Primary School)

\begin{tabular}{|c|c|c|c|c|c|c|c|c|c|c|c|c|c|c|}
\hline Year & $\cdots$ & ㅎํ & ஜั & ఫ্ & ॠ & ஜั & $\begin{array}{l}\text { Ð } \\
\stackrel{0}{0}\end{array}$ & $\stackrel{\varpi}{\Xi}$ & $\begin{array}{l}\vec{\nabla} \\
\stackrel{N}{N}\end{array}$ & $\begin{array}{l}\vec{\sigma} \\
\stackrel{\omega}{\omega}\end{array}$ & $\begin{array}{l}\vec{\sigma} \\
\stackrel{5}{+}\end{array}$ & $\begin{array}{l}\text { ज् } \\
\text { ù }\end{array}$ & 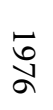 & $\stackrel{\vec{\sigma}}{\mathrm{v}}$ \\
\hline $\begin{array}{l}\text { Number and } \\
\text { calculation }\end{array}$ & $\ldots$ & 9 & 15 & 23 & 4 & 13 & 25 & 16 & 19 & 21 & 10 & 32 & 37 & 47 \\
\hline $\begin{array}{l}\text { Quantity and } \\
\text { measurement }\end{array}$ & $\ldots$ & 8 & 12 & 12 & & 11 & 8 & 5 & 2 & 10 & 9 & 6 & 7 & 9 \\
\hline $\begin{array}{l}\text { Geometrical } \\
\text { figures }\end{array}$ & $\ldots$ & 7 & 17 & 17 & 2 & 16 & 18 & 10 & 17 & 12 & 19 & 25 & 33 & 26 \\
\hline Problem solving & & 20 & 33 & 27 & 8 & 12 & 9 & 5 & 6 & 9 & 3 & 6 & 8 & 11 \\
\hline Sets & & & & & 25 & 25 & 13 & 14 & 11 & 9 & 2 & 7 & 4 & 5 \\
\hline Function & & & & & 31 & 18 & 19 & 15 & 18 & 17 & 16 & 20 & 26 & 11 \\
\hline $\begin{array}{l}\text { Probability and } \\
\text { statistics }\end{array}$ & & & & & 0 & 21 & 13 & 14 & 13 & 15 & 8 & 14 & 9 & 7 \\
\hline $\begin{array}{l}\text { Mathematical } \\
\text { thinking }\end{array}$ & & & & & & & & & & & 14 & 15 & 7 & 14 \\
\hline
\end{tabular}


As shown in the following section, the research on evaluation and concretization of mathematical thinking has been developed simultaneously, while the above type of analysis continued. Both of these approaches - the analytical research and the concretization - we see as the different sides of the same coin, and they have been influencing and referring to each other and deepening as a whole the field of enquiry related to mathematical thinking.

\section{Evaluating and developing the mathematical thinking through the Open-ended approach}

For six years between 1971 and 1977, Mathematics education researchers in NIER (National Institute of Education Research): university professors, primary and secondary school teachers, formed an interest group and developed the research project, whose theme was to develop evaluation method of mathematical thinking, through the Grant-in-Aid by the Ministry of Education, Culture and Sports. This group, consisting of about 30 members, scrutinized the objectives of primary mathematics education carefully and stated that "mathematical thinking has been flowing at the bottom of mathematics education in Japan since mathematical ideas in Jinjo-shogakusanjutsu (the national textbook during the pre-war period, Grade 1 of which was published by the Ministry in 1935) aiming to develop mathematical and scientific thinking, and the course of study in primary and junior secondary schools has already clearly stated it in 1958 and in senior secondary school in 1956. ... In short, to be able to develop mathematical thinking can be regarded as the ultimate goal of mathematics education" (Hasihmoto, 1976: 21-22).

This interest group further conducted the survey questioning a wide array of stakeholders, from mathematicians, mathematics education researchers, to mathematics teachers across Japan, regarding some behavioral examples of primary and secondary students attaining the objectives of mathematical thinking. The group summarized the find- ings from the answers about mathematical thinking as containing the following items (Hashimoto, 1976: 22), that are not necessarily independent from each other:

1. Being able to find out relations that underline the situation within a problem and begin to construct it mathematically.

2. Being able to solve non-routine problems which cannot be solved by common procedures.

3. Being able to develop something new.

4. Being able to fulfill one's own ideas in the group.

5. General objectives (under the current course of study).

Following these findings, the researchers repeated the process of developing the Open-ended problems for evaluation and trialed them in classroom. They had hypothesis that attainment level of mathematical thinking can be assessed through such incomplete Open-ended problems. They used these problems in the lessons and let students find out as many relations as possible and describe mathematically those relations. Evaluation is done by analyzing the relations in terms of quantity and quality, which is sophistication level of their description (Sawada \& Hashimoto, 1972: 65).

The notable point for this project is that it focuses not only on evaluation method but also on effective teaching strategies to realize development of mathematical thinking. This basic stance of the group influenced the direction of the research.

The research theme for the first year following the research project was "development research on evaluation method in mathematics education" but it was changed for the second and third year into "development of evaluation method in mathematics education and analysis of impact of various factors". Analysis of the factors is made possible by the fact that data collection at the classroom level had been done intensively from the beginning of this de- 
velopment work. In fact, the work done in the project paid attention to the students' group discussions during the lesson and tried to evaluate the change of this group discussion for the second year (Sawada \& Hashimoto, 1972).

The experience and knowledge gained through the research project, and which have been accumulated through the data collection regarding students' responses, prompted the group to shift from "development work of evaluation method for mathematical thinking" to "development of teaching strategies for mathematical thinking." Even after this, students' responses in the lessons had been continuously collected in parallel to sophistication of evaluation method. And gradually they become a new standard of teaching strategy.

The report for fifth year stated that the objective was "This year it aimed at trialing a few incomplete open-ended problems in the lesson during the second semester and confirming through statistical survey if this form of teaching can promote the attainment of the above objectives, and showed also the following results from teachers' observation and students' remarks" (Shimada, 1976, 29-30):

a. The middle and low achievers with less activity have become more active in expressing their ideas. (It is the same as the previous year).

b. Especially the middle achievers in the daily activity have made most remarkable progress in elementary and junior secondary schools. (It is the same as the previous year).

c. Some of the high achievers in senior high schools have performed less than previous year, since they become too careful not to make a mistake. (It is the same as the previous year).

d. In the previous year, it was reported in elementary schools that there were a few students who showed interests in mathematical properties after finding them within an openended problem, but in this year there were many examples which showed students took interest in these properties.

In the same year, the following ideas about teachers' work were found to be the case.

e. It may not be possible to say that being incomplete makes the problem effective. Rather, a problem posed to students should not only be incomplete, but it should also have a certain direction towards a solution, and something that is produced by students while they work on it, should be mathematically significant.

f. The open-ended problem approach is effective both at the introduction and at the summary of the lesson. When there is a good problem at the introduction, the lesson development becomes interesting. When it is given at the end or while summarizing the lesson, it is useful to review various aspects learned.

As for the summary and future issues of the research, the two points were listed as follows.

The first point is that the two terms of the year during which the research project took place were too short to confirm effectiveness of the teaching approach based on open-ended problems. Changes that were expected would be more visible only after a longer time has been spent in dedicating time to mathematical thinking and open-ended problem solving in the classrooms. In this sense, it was recommended to plan the activity from the beginning of school year in the following year.

The second point is that the problems used in the lessons were diverse not only in results but also in the processes and contexts they represented. Consequently, they had given diverse results, which could not always be correlated or compared with each other.

And you can see in the above point, diversities were noted in the process of research on evaluation method of mathematical thinking, and they demanded the necessity of systematizing and theorizing them as mathematical activities. "Problem posing with diversity" was used as the evaluation method on devel- 
opment of mathematical thinking. In other words, mathematization of phenomenon was placed in the center of mathematical thinking, and it was assumed that possibility of such mathematization was not only one but also several, and so the significance of "being diverse" was to be re-considered. It is notable that the research group located this as the future issue.

This research resulted in perceiving mathematical activity as coming and going between real and mathematical world and locating it in the phases of the Open-ended approach, which extensively utilizes the incomplete problems (Figure 1). And Takeuchi employed theory of scientific knowledge growth by Popper and approached this issue from the perspective of the nature of mathematical activity (Takeuchi, 1976: 11-12). This consideration played an important role in shifting the research from the Open-ended approach to "extensive treatment of problems" (Takeuchi, 1984: 9-23). ${ }^{3}$

In this way, the developmental research of the Open-ended approach has continued as mutual interaction between theory and practice and the treatment of diversity in mathematical learning has become systematized.

\section{Diversified ideas in mathematics textbooks}

Lesson development like the one described above, and which used diversity of mathematical ideas has made an impact also on lesson structure. The textbooks published by one textbook company were compared by focusing on the area of plane figure (parallelogram) in the fifth grade. The textbooks from 1965 to 1975 (Figure 2) didn't have diversified ideas, but they has already started development of evaluation method of mathematical thinking using incomplete problems. The textbooks in 1980 (Fig-

3 Starting from one problem given to the children, which is called a original problem, children are encouraged to pose new problems through replacing the component of the original problem with similar and more general ones and considering the converse, and to develop subjective attitudes to solve the problems for themselves (Takeuchi, Sawada, 1984: 25). ure 3) and that in 1985 (Figure 4) contained more than one idea. They are different ways of "cutting into pieces and pasting them together" and "moving trapezium and matching the corresponded areas". We must remember that the latter took place after the Open-ended approach was proposed as teaching method in 1977. This leads to current textbook (Figure 5). Adoption of diversified ideas in the textbook produces the practical issues on how to treat them during the lesson.

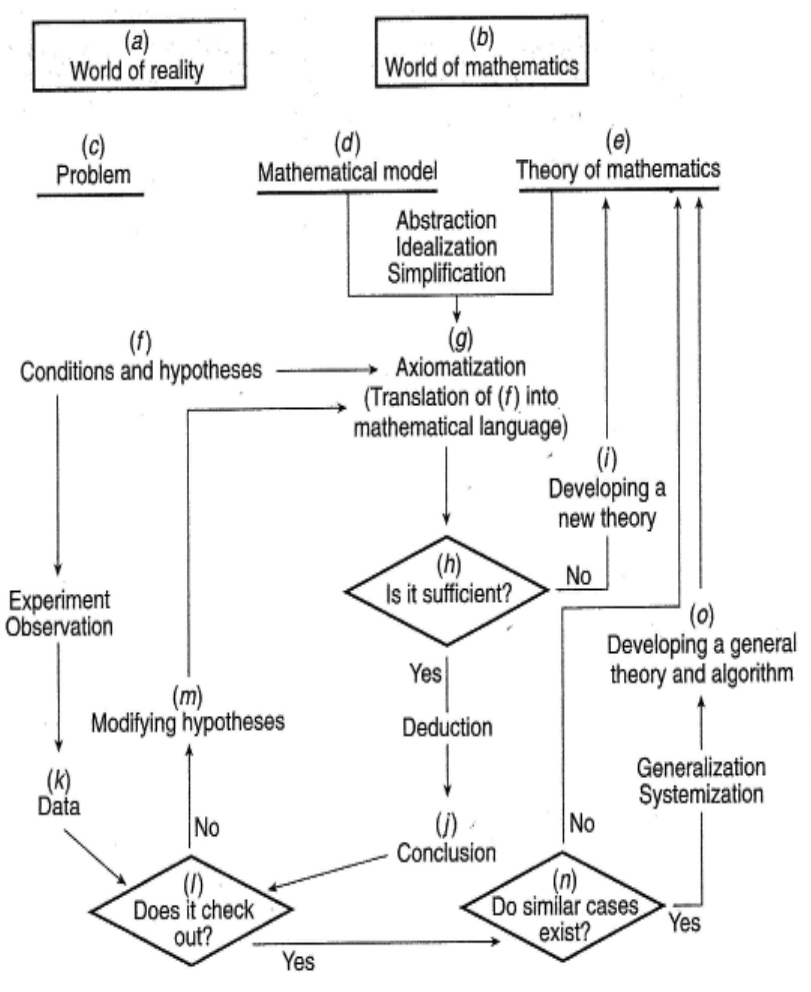

Figure 1. Model of Mathematical Activity (Shimada, 1977: 15) 


\section{5 图形の面皘}

四四角形・三危形の面精を求以る公式

[2] いろいろな形の面皘の求め方

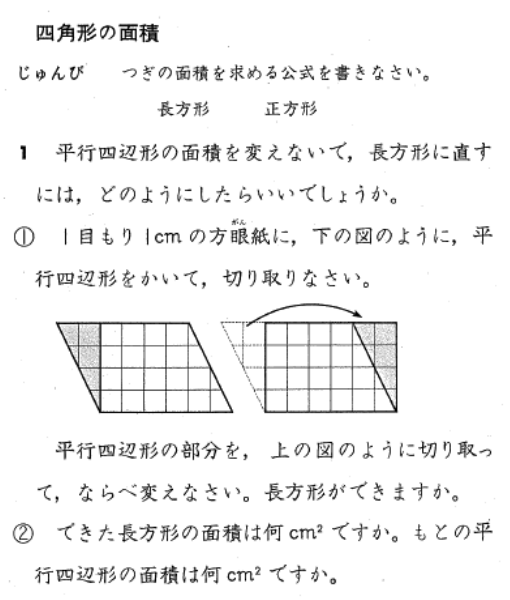

\section{四角形の面皘}

の面皘を求める公式を莒きなさい。 長方形正方形

平行四辺形の面積を变えないて，長方形に直す には,とのようにしたらいいてしょうか。

(1) |目もり $1 \mathrm{~cm} の$ 方眼紙に, 下の図のように, 平 行四边形をかいて，切り取りなさい。 50
2 平行四辺形の面皘を求めるには, とこととこの 長さがわかったらいいてしょうか。平行四辺形の 面積を求める公式を作りましょう。

(2) 右の平行四辺形て, もとに して考える边を庭辺といいま ナ。辺 $B C$ 底边としたとき, 底辺 $B C$ に跴直な直線 $A E$ や FG，DH を高さといいます。 高さは，とれも同し長さで。 $($ 平行四辺形の面皘 $)=($ 店辺 $) \times($ 高き $)$

3 右の図のような平行四边形 があります。

(1) 辺ABを底辺としたとき, 高 さは何 $\mathrm{cm}$ てすか。

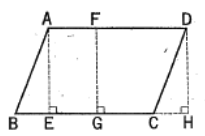
边BCを底辺としたとき, 高さは何 $\mathrm{cm}$ てすか。

(3)上の平行四辺形の面啨老, 辺 $A B$ を底边として 求めなさい。

また, 辺BC を咸边として求めなさい。

Figure 2. Mathematics textbook in 1974

2 平行四辺形の面積を求めるには，とこととこの長さ がわかったらいいでしょうか。

平行四辺形の面掼を求める公式を考えましょう。

平行四辺形では， |.つの 辺を底边とします。底边と 威辺に平行な辺の間の辰さ は,とこも同じてすっれ を高さといいます。 平行四辺形の面積 $=$ 底辺 $\times$ 高さ

3 右の图の平行四辺形 $\mathrm{ABCD}$ で, 辺 $A B$ を底辺とすると, 高さは何 $\mathrm{cm}$ か、はかってみましょう。

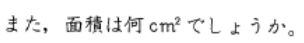

\section{"}

つぎの平行四辺形の面積を求めなさい。

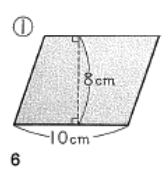

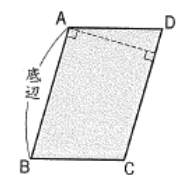

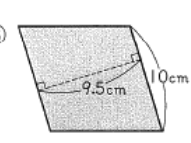

4 右の図の上うに, 辺 $B C$ を咸辺と する平行四辺形の面積を求めると きにも、公式があてはまることを、 下の图を見て説明しましょう。

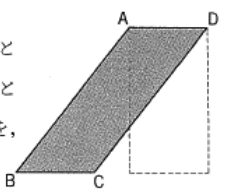

（1）ただし君の考え

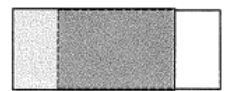

(2)ゆき子さんの考え

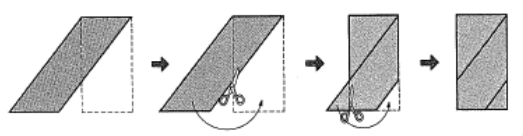

(3) かずお君の考え
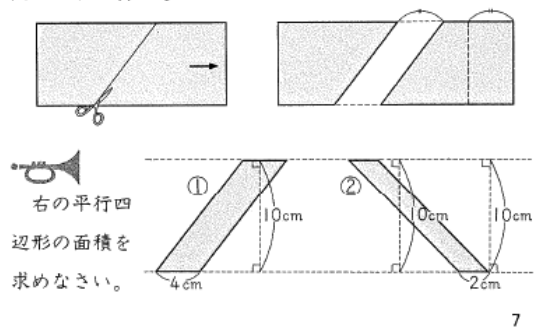

Figure 3. Mathematics textbook in 1980 
平行四辺形では, |つの边 を䉀边とします。底辺イウ に童䈯に引いた直線アキ， オカなどは,とこも同じ長

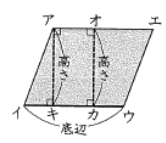

さです。これを，底辺イウに対する高さといいます。 平行四辺形の面積 $=$ 底辺 $\times$ 高さ

3 右の平行四辺形の面耤は

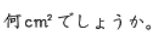

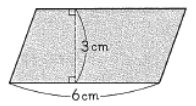

4 右の図は平行四辺形です。

(1) 辺アイを虏辺とすると，高さは 何 $\mathrm{cm}$ か，はかってみまし上う。

（2）面耫を求めましょう。

ros

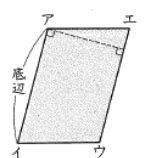

次の平行四辺形の面積を求めなさい
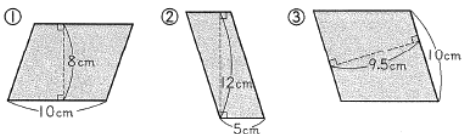

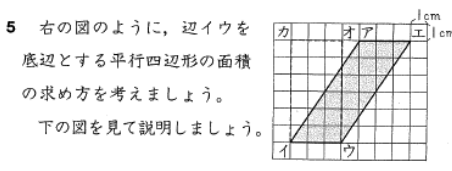

(I) ただし君の考え

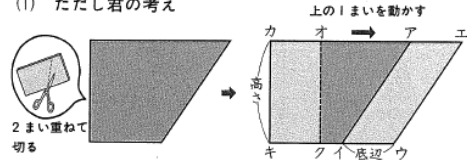

(2) か书るさんの考え

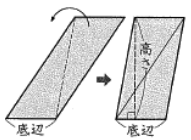

(3) 心ききたの考え

10

次の平行四辺形の面積を求めなさい。

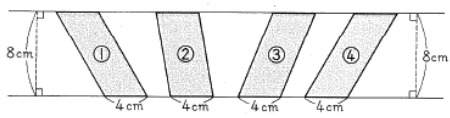

Figure 4. Mathematics textbook in 1985

3

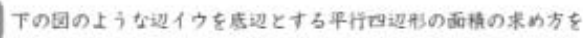
$5 x \pm L 25$.
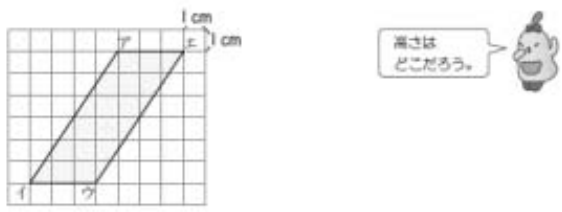

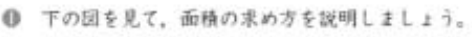
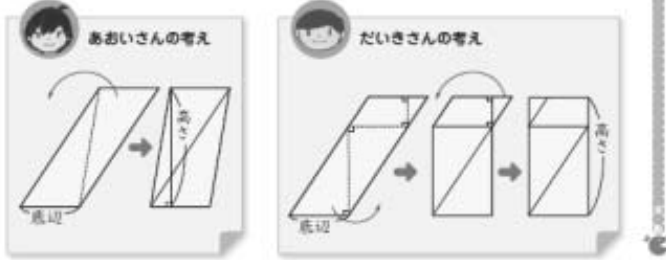

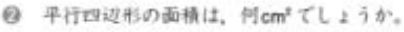

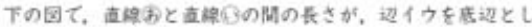

$た と き の$, 平行四边丹!

イウエの高さに吾リまナ。

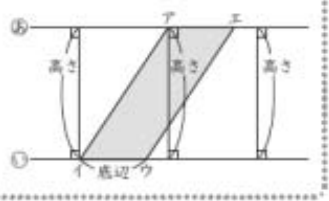

Figure 5. Mathematics textbook 2010 


\section{Research on how to treat and summarize diversified ideas}

The diversification of ideas as the ones shown above which made their way into the Japanese textbooks have influenced the developmental research on how children treat and summarize different mathematical ideas during the learning process. "One objective of the problem solving through diversified ideas is to ensure acquisition of the basic knowledge and skills and the understanding of mathematical thinking which can be encountered in the process of learning through presentation of those ideas, and to aim at the development of individual student's holistic growth including cognitive understand, emotional development and explaining skills through the whole class participation" (Koto, 1992, 19). Koto further stated that diversified ideas should lead to development of mathematical thinking.

Koto (1992, 1998) classified diversified ideas, which can be observed during mathematics lesson, in terms of teaching aims and quality, and proposed the instruction flow utilizing them as follows:

Independent diversity: Paying attention to validity of each idea

Prioritized diversity: Paying attention to efficiency of each idea

Integrated diversity: Paying attention to commonality of each idea

Structured diversity: Paying attention to mutual relations between ideas.

The research on how to treat and summarize the diversified ideas is regarded as one of the necessary items for the lesson study in Japan in the spe-

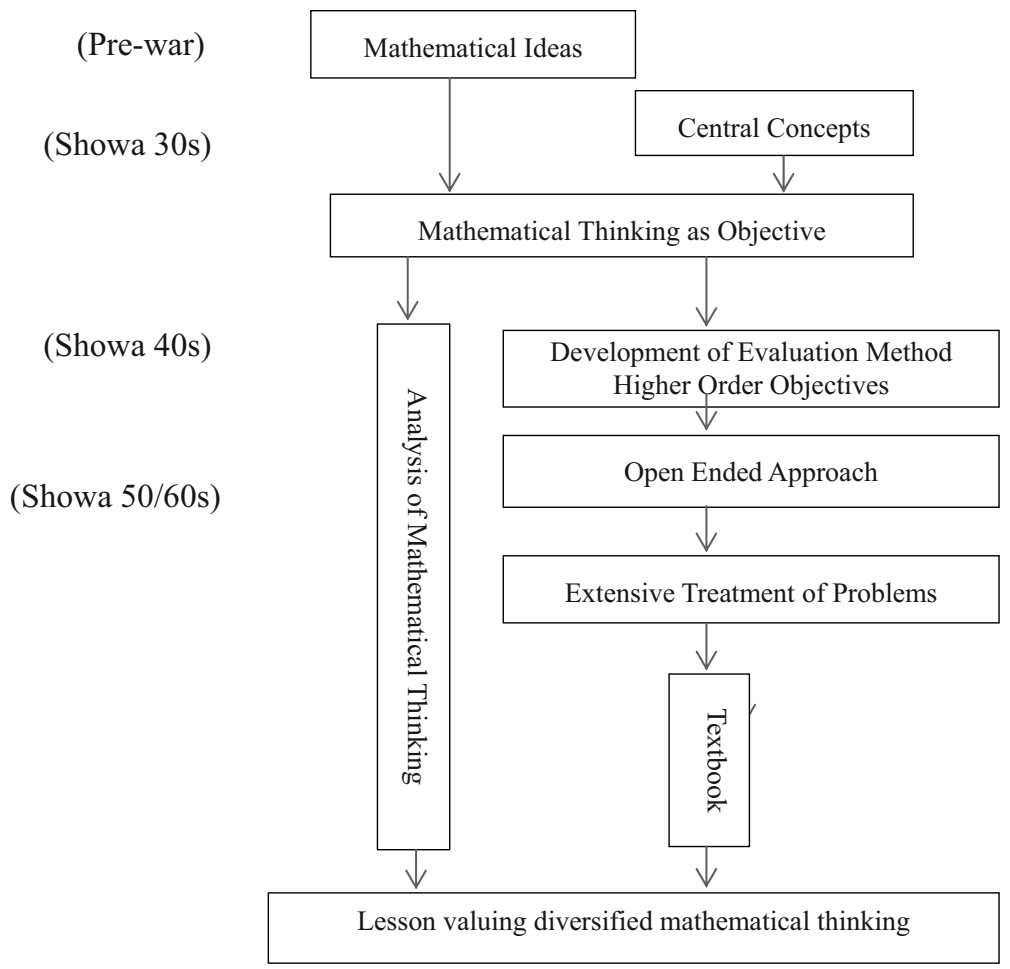

Figure 6. Flow of Mathematics Education in Japan from the Perspective of Open-ended Approach 
cial issue Theory of mathematics education in $\mathrm{Ja}$ pan for lesson study, which was published by Japan Society of Mathematics Education (JSME) during EARCOME in 2010 (Wada, 2010). This shows the significance of research impact by Koto and others on the lesson development in Japan.

\section{Summary}

Engagement by Japanese mathematics education community regarding the open-ended approach can be summarized chronologically in the Figure 6.

Most primary mathematics teachers let the students construct mathematical ideas subjectively and extensively, and valued utilizing children's diversified mathematical ideas in the lesson. In this paper, the historical development was reviewed by taking up analytical and developmental researches on mathematical thinking. The latter described development research has changed its focus from evaluating the method of mathematical thinking through the open-ended approach to treatment of diversified mathematical ideas. The described history of transition from mathematical thinking, through open-ended problems to diversified ideas, shows the forming of shared values among the Japanese mathematics education community. Historical approach regarding research method, research themes and developmental processes of research can provide methodologically an important perspective to help us grasp values in mathematics education in each culture and society, not only Japan.

\section{References}

- Baba, T. (2006). 『数学的な考え方』から見た日本の数学教育の文化論[Cultural Aspect of Mathematics Education in Japan from the Perspective of Mathematical Thinking]. Journal of JASME Research in Mathematics Education, 12, 247-252. (in Japanese)

- Baba,T., Ueda, A. Osaka, N., Iwasaki, H., Kinone, C., Soeda, Y., \& Shinno, Y. (2013). 数学教育における 価值についての国際比較調査「第三の波」（1）－全体的傾向および集団間の比較考察－[International Comparative Study 'The Third Wave” Regarding Values in Mathematics Education 1 - General Trends and Comparative Study among Target Groups], Journal of JASME Research in Mathematics Education, 19(2), 127-140. (in Japanese)

- Becker, J. \& Shimada, S. (1997). The Open-ended Approach: A New Proposal for Teaching Mathematics. The National Council of Teachers of Mathematics.

- Hashimoto, Y. (1976). 高次目標の意義 [Significance of Higher-order Objectives]. in Scientific Research Grant-in-Aid Report, Ministry of Education, Culture and Sports. Developmental Research on Evaluation Methods of Higher-order Objectives in Mathematics Education (14-23). (in Japanese).

- Japan Society of Mathematical Education (JSME). (2010). Special Issues EARCOME 5 Mathematics Education Theories for Lesson Studies: Problem Solving Approach and the Curriculum through Extension and Integration, Japan Society of Mathematical Education.

- Katagiri, S., Sakurai, T., Takahashi, E., Oshima, T. (1971). 数学的な考え方とその指導〔小学校編] [Mathematical Thinking and its Teaching (Primary School Editions)]. Modern Shinsho Printed. (in Japanese)

- Katagiri, S. (1988). 数学的な考え方・態度とその指導 [Concretization of Mathematical Thinking and Attitudes and the Teaching]. Meiji-tosho. (in Japanese) 
- Koto, R. (1992). 算数科 多様な考えの生かし方まとめ方 [How to Utilize and Summarize Diversified Ideas in Primary Mathematics Education]. Toyokan-shuppan. (in Japanese)

- Koto, R. (1998). コミュニケーションで創る新しい算数学習 一多様な考えの生かし方まとめ方一 [New Primary Mathematics Education Created by Communication - How to Utilize and Summarize Diversified Ideas]. Toyokan-shuppan. (in Japanese)

- Nakashima, K. (1981). 算数・数学教育と数学的な考え方 一その進展のための考察一 [Mathematical Thinking at Primary and Secondary Mathematics Education: Consideration of its Development]. Kaneko Shobo. (in Japanese)

- Sawada, T. \& Hashimoto, Y. (1972). 数学教育の評価方法に関する開発研究 一未完結な問題によ る児童・生徒の反応についてーその 1 . 数学科における未完結な問題場面による評価と従来の 評価との関係，その 2 . 未完結な問題における個人反応とグループ反応との比較[Developmental Research on Evaluation Methods in Mathematics Education - Students’ Responses against Incomplete problems - Part 1 Relation between Evaluation using Incomplete problems and Traditional Evaluation, Part 2 Comparison between Individual Responses and Group Responses against Incomplete Problems]. in Proceedings of the $7^{\text {th }}$ Annual Conference, Japan Society of Mathematics Education, 65-70 and 71-74. (in Japanese)

- Shimada, S. (1977). 算数・数学科のオープンエンド アプローチ 授業改善への新しい提案[Openended approach in Mathematics Education- New Proposal of Lesson Improvement]. Mizu-umi shobo. (in Japanese)

- Shiono, N. (1970). 数学教育論 [Discussion on Mathematics Education]. Keirin-kan. (in Japanese)

- Stigler, J. W., \& Hiebert, J. (1999). The teaching gap: Best ideas from the world's teachers for improving education in the classroom. New York: Free Press.

- Takeuchi, Y. (1976). 数学的認識の成長について[Growth of Mathematical Cognition], in Scientific Research Grant-in-Aid, Ministry of Education, Culture and Sports. Developmental Research on Evaluation Methods of Higher-order Objectives in Mathematics Education (1-15). (in Japanese)

- Takeuchi, Y. (1984). 問題から問題へ [From problem to Problem]. in Takeuchi \& Sawada (ed.) From Problem to Problem - Extensive Treatment of Problems for Improvement of Mathematics Lesson. Toyokan shuppan. (9-23). (in Japanese)

- Takeuchi, Y. \& Sawada,T. eds (1984). 問題から問題へ 問題の発展的な扱いによる算数・数学科の 授業改善 [From Problem to Problem -Extensive Treatment of Problems for Improvement of Mathematics Lesson]. Toyokan shuppan. (in Japanese)

- Ueda, A. (1983). わが国の算数教育における「問題解決の捉え方」 [Viewpoints of "Problem Solving" in Primary Mathematics Education in Japan]. Proceedings of Graduate School of Education, Hiroshima University. 9. 135-141. (in Japanese)

- Ueda, A. (2006. 「数理思想」と「数学的な考え方」という言葉が出てきた歴史的背景[Historical Reviews for the emergence of "Mathematical Ideas" and "Mathematical thinking" as Terminology in Mathematics Education in Japan]. Journal of JASME Research in Mathematics Education. 12. 248. (in Japanese)

- Wada. S. (2010). 比較検討の手順を中心に [Procedure of Comparative Studies]. Special Edition Mathematics Education Theories for Lesson Studies. Journal of Japan Society of Mathematics Education. 92(11). 42-43. (in Japanese) 


\section{мр Ацуми Уеда}

Педагошки факултет, Универзитет у Хирошими, Јапан др Такуја Баба

Педагошки факултет, Универзитет у Хирошими, Јапан

\section{мр Такето Мацура}

Педагошки факултет, Универзитет у Хирошими, Јапан

\section{Вредности јапанског математичког образовања из перспективе „отвореног приступа“}

Књига „Јаз у настави“ (Stigler \& Hiebert, 1999) привукла је пажњу стручне јавности представљањем међународној заједници „студије часа“ и јапанског математичког образовања, посебно дискутујући о „студији часа“. Са друге стране, асоцијација JASME (Japan Academic Society of Mathematics Education) одржала је симпозијум током 22. годишње конференције на тему културног аспекта у математичком образовању у Јапану. Да је „студија часа“ континуирано и екстензивно развијала „математичко мишљење“ као образовну вештину, истражујући и њен будући правац развоја кроз саморефлексију њених карактеристика, потврдио је Баба (Baba, 2006). У овом раду се на математичко мишљење историјски гледало више из перспективе наставника у основној школи, у смислу евалуације и метода рада, промена насталим у уџбеницима и истраживању различитих математичких идеја. „Отворени приступ“ је узет као пример, јер се односи на све наведене аспекте. „Математичке идеје“ као филозофско питање у националном уџбенику Jinjo-shogaku-sanjutsu се користе од 1935. године (Ueda, 2006). И пре појаве термина „математичко мишљење“ у настави средње школе још од 1956. године постојао је термин „централни појам“, са намером да се издвоје математичке методе и активности заједничке алгебри и геометрији и да се интегришу у један предмет. Наведени термин „централни појам“није био истоветан термину „математичко мишљење“, али је сигурно утицао на његово увођење. Онда се нов термин појавио 1958. године као циљ курса основношколског образовања. И кроз прихватање математичког мишљења, од ученика се очекивало да досегну нове идеје самостално и да користе математичке чињенице и односе међу њима смислено и ефикасно, да их изражавају и да промишљају о њима на концизан начин, и да тачно поступају са њима, независно и рационално. Упркос свим напорима, значење новог термина у то време није било јасно. Катагири (Katagiri et al., 1971; Katagiri, 1988) анализирао је значење и категоризовао математичко мишљење. Накашима (Nakashima, 1981) математичко мишљење схватао је као способност самосталног рада и остао је при идеји да је то аутономни и креативни процес. Кроз рад Катагирија и Накашиме, значење новог термина постало је јасније. Од 1971. године, па наредних шест година, истраживачи у Институту NIER (National Institute of Education Research), професори универзитета и наставници у основним и средњим школама формирали су интересну групу и развили истраживачки пројекат чија је тема била развијање евалуационог метода математичког мишљења, који је касније назван „отвореним приступом“ (Shimada, 1977). Пројекат је користио активно незавршене проблемске ситуације, које су стварале разноликост не само по резултатима већ и у самом процесу и контекстима. Искуство и знање које су ученици стицали у пројекту акумулирани су кроз скупљање података који су се односили на одговоре ученика и чинили да се пројекат развије од „евалуационог мо- 
дела за математичко мишљење“ до „наставне стратегије за математичко мишљење“. Није довољно имати различите идеје шта деца могу, већ треба потврдити да ове идеје имају образовну вредност. Да би се утврдиле овакве идеје, неопходно је организовати смислене математичке активности у теорији. То нас је довело до схватања математичке идеје као нечег између стварног и математичког света, што је имало за сврху различите идеје које се појављују при решавању незавршених проблема. Такве идеје класификовао је Кото (Koto, 1992, 1998) у терминима циљева и квалитета учења и предложио је постојање инструкција за учење. Истраживање је имало огроман утицај на развијање система часова у Јапану. Коначно, откривено је да је „отворени приступ“ остао основна карактеристика јапанског математичког образовања. Анализа значења „математичког мишљења“, развој евалуације, те развој самог термина сигурно су били у међусобној интеракцији и развијали се као целина. Претпоставка је да су сви они имали огроман утицај на укупну вредност математичког образовања у Јапану. А историјска анализа може да омогући једном методичком приступу да појасни и релативизује вредности математичког образовања у различитим временима сваке културе.

Клучне речи: вредност, „отворени приступ“, историјска анализа, „математичко мишљење“. 